\title{
Confirmation that Helopeltis species attacking cacao in Yogyakarta is Helopeltis bradyi Waterhouse, not Helopeltis antonii Signoret (Heteroptera: Miridae)
}

\author{
Konfirmasi spesies Helopeltis yang menyerang kakao \\ di Yogyakarta sebagai Helopeltis bradyi Waterhouse, bukan \\ Helopeltis antonii Signoret (Heteroptera: Miridae) \\ Susi Melina $^{1^{*}}$, Edhi Martono², Y. Andi Trisyono ${ }^{2}$ \\ Departemen Proteksi Tanaman, Fakultas Pertanian, Universitas Gadjah Mada \\ Jalan Flora No. 1 Bulaksumur, Sleman, Yogyakarta 55281
}

(diterima Juni 2015, disetujui Januari 2016)

\begin{abstract}
Helopeltis antonii Signoret (Heteroptera: Miridae) has long been reported to attack cacao and other host plants in Java. A recently published literature review refuted this idea and offered morphological evidence suggesting that this attacker is actually Helopeltis bradyi Waterhouse. However, through the present, local reports still identify attacks as coming from $H$. antonii. To confirm which of these two species is implicated in cacao damage, we conducted an examination of the external morphology, genitalia and the biology of Helopeltis sampled from infested cacao plants in Yogyakarta. 42 females and 9 males, sampled from 3 different locations, were observed to be morphologically similar to $H$. bradyi, especially with regard to the pale band on the base of all femora, the knife-shaped male lobal sclerite, and the presence of a ' $\mathrm{Y}$ ' shaped junction on the posteriorly fused female genital chamber. The duration of the life stages (in days) of the laboratoryreared insects were: 7-11 (eggs), 12-19 (nymphs), 9-44 (female) and 16-54 (male) d, measurements which fall within the ranges of the parameters usually reported locally for $H$. antonii, with the exception of male adult life stages which are longer than the aforementioned reports. Morphological changes were observed during all stages of development, including within adult stages. In female adults specifically, external morphology and genital development proceeded continuously until the insects reached the full-grown condition, characterized by stable color, and fully sclerotized genital chamber. Our preliminary study of the morphology and development of lab-reared insects descended from individuals infesting cacao fields, indicated the presence of $H$. bradyi instead of $H$. antonii in Yogyakarta, and therefore stipulated a need to review the existence of the latter in Indonesia.
\end{abstract}

Key words: biology, external morphology, genitalia, identity

\begin{abstract}
ABSTRAK
Helopeltis antonii Signoret (Heteroptera: Miridae) sering dilaporkan menyerang kakao serta beberapa tanaman inang lain di Jawa. Meskipun sebuah studi telah membantah dan membuktikan secara morfologi bahwa spesies yang sebenarnya adalah Helopeltis bradyi Waterhouse, hingga saat ini publikasi lokal masih terus mencantumkan nama $H$. antonii. Untuk mengkonfirmasi spesies mana yang sebenarnya menimbulkan kerusakan, maka dilakukan pengamatan morfologi luar, kelamin, serta biologi dari Helopeltis yang dikumpulkan dari pertanaman kakao di Yogyakarta. Sampel yang terdiri dari 42 betina dan 9 jantan dari 3 lokasi berbeda menunjukkan kesamaan morfologi luar dan kelamin dengan $H$. bradyi, terutama dari adanya pita pucat pada pangkal setiap femur, lobal sclerite jantan yang berbentuk pisau, dan struktur seperti huruf ' $\mathrm{Y}$ ' dengan bagian belakang sclerotized
\end{abstract}


ring yang menyatu pada genital chamber betina. Fase telur, nimfa, imago betina, dan jantan berturut-turut 7-11, 12-19, 9-44, 16-54 hari, mendekati kisaran yang dilaporkan untuk H. antonii secara lokal selama ini, kecuali untuk jantan. Perubahan morfologi luar terjadi pada semua fase kehidupan serangga, termasuk imago. Pada imago betina khususnya, perubahan morfologi dan kelamin berlangsung sejak imago terbentuk hingga tumbuh sempurna dimana tidak terjadi lagi perubahan warna, sedangkan sklerotisasi kelamin sudah tuntas. Penelitian awal ini mengkonfirmasi keberadaan H. bradyi, bukan H. antonii di Yogyakarta, sehingga diperlukan tinjauan ulang keberadaan $H$. antonii di Indonesia.

Kata kunci: biologi, identitas, kakao, kelamin, morfologi luar

\section{INTRODUCTION}

Helopeltis spp. (Heteroptera: Miridae) is regarded as one of the major estate crop pests in Indonesia. In 2011, its infestation of cacao crops in Java, Bali, and Nusa Tenggara was recorded over 1,361, 863, and 21,747 ha respectively, which together accounted for $25.1 \%$ of the total cacao planted in these islands, and representated a quadrupling of the area infested in just two years (BBP2TP Surabaya 2011). The possibility of even more severe damage must now be addressed as up to $60 \%$ of the final yield can be lost in a heavily infested cacao estate (Djamin 1980; Puslitkoka 2004). Unfortunately, the pest control methods usually employed, yield varied results. possibly as a result of misidentification of the pest species. The correct identification of an insect pest is necessary as the basis of biological control and valid research (de Moraes 1987); however, a lack of information on the ecology and systematics of agricultural pests, including Helopeltis, is common (Miller \& Rossmann 1995).

Confirmation of the species identity of the commonly reported Helopeltis in Indonesia as $H$. antonii, remains partly unresolved (see Stonedahl 1991; Wiryadiputra 1997). Similarity of external morphological characters to other related pests, can lead to misidentification (Stonedahl 1991). This is even more likely to happen given that the early works on the taxonomy of Helopeltis genus relied mostly on external morphology, especially body measurements, shape, and coloration (e.g. Signoret 1858; Walker 1873; Waterhouse 1886 \& 1888; Bergoth 1889). Furthermore, recent taxonomic works on the prevalent local species of this genus are very rare. Waterhouse (1886) described $H$. bradyi, which damaged chincona plantations in Java. Morphologically, $H$. bradyi is similar to $H$. antonii, however the former has a slightly larger body size (Atkinson 1897). Waterhouse (1888) reported another species of Helopeltis on Javanese tea, which was given the name of $H$. romundei. However, a review conducted by Stonedahl (1991) on the oriental species of Helopeltis suggested that only $H$. bradyi is present in Indonesia and is mistakenly reported as $H$. antonii, and that $H$. romundei and H. ceylonensis in Sri Lanka (De Silva 1957) are all synonymous to $H$. bradyi. To come to this conclusion, Stonedahl (1991) examined both external morphology and the genitalia, especially the lobal sclerite of the male phallus and of the the genital chamber of female Helopeltis. Based on his morphological findings, he reported nine Helopeltis species could now be found in Indonesia; $H$. bradyi, $H$. chinconae, $H$. bradyi, $H$. cuneata, H.fasciaticollis, H. insularis, H. sulawesi, $H$. sumatranus, and $H$. theivora. On the contrary, he concluded that $H$. antonii is restricted to India, Sri Lanka, and Andaman Islands. Despite these findings, most of the recent local publications still refer to $H$. antonii rather than $H$. bradyi, e.g. Kilin \& Atmaja 2000; Siswanto et al. 2008; Karmawati 2010; Atmadja 2012).

The morphological similarity between $H$. antonii and $\mathrm{H}$. bradyi, the early report of Waterhouse (1886), as well as the revision of Stonedahl (1991) regarding these two species, support the notion that $H$. bradyi is the Helopeltis species most likely to be found in Java. However, it is also possible that, more than 20 years after Stonedahl's (1991) review, $H$. antonii has now spread in Indonesia. Therefore, to definitively identify the infesting Helopeltis species in Yogyakarta, we conducted a preliminary morphological examination on their external and genital characters, and observed the biology of the laboratory reared individuals. Thus, this study is the first attempt to confirm which Helopeltis species currently infests cacao in Yogyakarta. 


\section{MATERIALS AND METHODS}

\section{Helopeltis}

The Helopeltis utilized in this study were collected in February 2012 from cacao orchards at the following villages; Banjaroyo (208 m asl; $\left.7^{\circ} 40.385 \mathrm{~S}-110^{\circ} 15.344 \mathrm{E}\right)$, Putat $(190 \mathrm{~m}$ asl; $7^{\circ} 51.983$ S- $110^{\circ} 31.993^{\prime}$ E), and Sawahan (478 $\mathrm{m}$ asl; $\left.7^{\circ} 54.615 \mathrm{~S}-110^{\circ} 45.200 \mathrm{E}\right)$ of Yogyakarta (Figure 1). A mixture of nymphs and adults were captured; 12 female and 2 males in Banjaroyo; 23 female and 7 males in Putat; and 7 females in Sawahan. The collected insects were kept in groups according to their location of origin. Prior to microscopical examination, the adults were first allowed to mate and lay eggs on cucumber fruit following the method of Sudarmadji (1979) and Kilin \& Atmadja (2000), in an air conditioned room (ca. $23{ }^{\circ} \mathrm{C}, 70 \% \mathrm{Rh}$ ) for one week, to initiate the laboratory colony.

\section{Morphological characteristics}

All studies were conducted in the Basic Entomology Laboratory, Faculty of Agriculture, Universitas Gadjah Mada, Yogyakarta. A Leica KL 1500 LCD dissecting microscope (Leica Microsystems GmbH, Wetzlar, Germany), equipped with ocular and stage micrometer allowed for the observation and measurement of Helopeltis body parts. The adults were first immobilized in a freezer at $-2{ }^{\circ} \mathrm{C}$ for $5 \mathrm{~min}$ or dipped into $70 \%$ EtOH before microscopical examination. They were examined for the morphological characters that distinguish different Helopeltis species, including body colour, shape, and dimension. The adults were then dissected in order to measure the dimensions of the eggs within the gravid females, and the shape of the genitalia of both sexes. The genitalia, viz. male lobal sclerite and female genital chamber, were extracted from the genital capsule (abdominal sterna IX in male, VII-IX in female). These structures were dipped in $10 \% \mathrm{KOH}$ ca. $24 \mathrm{~h}$ to remove bodily tissues and fat. All characters were microscopically observed, and compared to the images in the latest review of the oriental Helopeltis (Stonedahl 1991). The morphological terms employed in this study are those used in the Stonedahl review.

\section{Life stages and morphological changes}

The observation of the external morphology and genitalia of the collected adults indicated that only one species - the same species - was present in all 3 plots sampled. Therefore, it was only necessary to select one population for further study; the Banjaroyo population. Two cucumber fruits from Banjaroyo, on which adult females previously oviposited, were selected. Fifteen first instar nymphs previously recorded for the length of their egg period, were collected from each fruit. Each of these nymphs was transferred to individual vials of $10 \mathrm{~cm}$ diameter and $7 \mathrm{~cm}$ height. The insects were fed with $1 \mathrm{~cm}$-thick, halved cucumber slices. The slices were replaced every other day with larger slices given as the insects grew. The duration of instar and adult stages, and the ratio between males

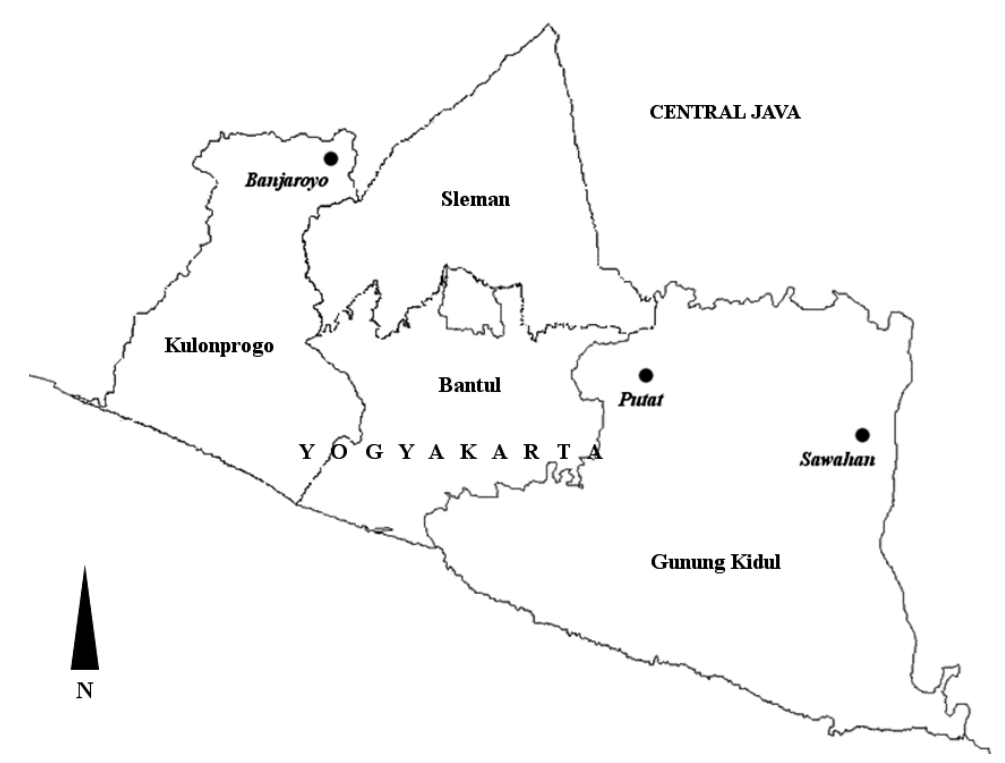

Figure 1. The collection sites of Helopeltis samples in Yogyakarta. 
and females were recorded. Ten male/female pairs of newly emerging adults were selected for mating, and each was transferred to a plastic bottle with a fresh, whole cucumber fruit. When the mating period started, the cucumber fruit was replaced every day until the female died. The collected fruits were observed for the number of oviposited eggs. If a male in a pair was still alive, it was observed further until it died. A batch of nymphs was selected from the offspring of the mating pairs, for body measurement and morphological observation. Nymphs that hatched on the same day were separated and reared individually. Ten nymphs were selected in order to measure each during the instar phase. Morphological characteristics of the nymph instars-such as colouration, the presence or absence of setae, scutellar spine, and wing buds during each stage of development, were recorded.

\section{RESULTS}

\section{The collected adults}

Coloration. The newly moulted adults were pale orange in coloration which darkened with age. The males more readily turned darker, and at maturity were darker than the females. Head (Figure 2A, 2B). The head was short and black, with prominent but not stalked eyes. The general colouration of the head was dark brown for the female and infumate (blackish) for the male. The tylus (clypeus) was pale brown and covered with setae, lora (maxillary plates) and juga (mandibulary plates) are fuscous with pale anterior edge. Pale spots were observed directly under the faceted eyes, and lateral to the gena (cheek) (Figure 2B). The gula (neck) was dark except in newly born adults. The first antennal segment was thickened distally with a pale band basally, while the other three segments were thinner, darker, and covered by minute setae. The rostrum extends beyond the mesothoracic segment which has a paler first segment; the tip was darkest. Pronotum (Figure $2 \mathrm{~A})$. The pronotum was dark red in mature females and orange-yellow in newly moulted adults. The mature males have a dark fuscous pronotum. The pronotum was curved and wider at the posterior end, while the anterior part was narrower to create a short collar at the anterior end. The scutellum was more or less semi-circular, and the scutellar spine almost straight, with pale basal and darker distal parts. The round knob on the tip of the scutellar spine was covered with dark, short setae. Legs and wings (Figure 2A). The legs were long and slender, and the femora were strongly nodulated, with a pale band around the basal third of the fore, middle and hind femora. The tibiae were black and setaceous, the setae becoming denser towards the distal end. The tarsi were densely setaceous with large claws. The wings were semi-transparent. The hemelytron was a one cell structure, elongated, extended beyond the abdomen, and infumate with dark venation. The hind-wing was without cells and lightly infumate. Abdomen (Figure $2 \mathrm{C}-\mathrm{D}$ ). in newly moulted females, the first three and last four abdominal segments were covered by infumate patches. With age, all of the latero-abdominal segments of mature females were covered by dark patches; on males of any age, the dark patches only covered the first three and the last four segments. The abdomen of the males was smaller and flatter, and at rest was completely covered by their wings. By contrast, the abdomen of the females was bigger and rounder ventrally and protrudes laterally such that their wings at resting position are unable to cover it.

Survivorship and size. The average rate of survival of collected adults reared on cucumber fruit was $86 \%$. Females were consistently outnumbered by males; at a ratio of $34 \%$ females to $66 \%$ males (Table 1 ). The males were smaller than females in general (Table 2, 4). The mean length of the male and female body from head to wing was $6.50 \mathrm{~mm}$ and $7.75 \mathrm{~mm}$, respectively. The length of the head of both sexes was shorter than its width, the ratio being 0.64 and 0.61 for males and females respectively; the ratio of length to width of the thorax was the opposite, 1.13 and 1.35 respectively. The antennae were longer than the body, with a thicker 1st segment, that was shorter than the 2nd and 3rd segments, but longer than the 4 th. The 1 st segment however, was longer than the width of the posterior pronotum in a ratio of $1.74: 1-1.77: 1$ and $1.59: 1-1.62$ for male and female respectively. The hind femur were tibia are the longest sections of the legs, while the length of the middle and the fore legs were almost alike. The ratio of femur to tibia length was 0.76 for the front legs and $0.75-0.76$ for the hind legs respectively. 


\section{The genitalia}

Male lobal sclerite (Figure 2E). The lobal sclerite in the sampled males resembles a knife. The sclerite was pointed posteriorly, straight medially, strongly narrowed on the third part below the apex before it widened apically. Parameres (Figure $2 \mathrm{~F}$ ). The right and left parameres (claspers) were orange-brown; the right one was smaller, short, blunt apically, widened anteriorly, and twisted basally; the left one was long, curved, blunt apically, wide medially, with a sharp tapering base. Female genital chamber (Figure 2G-H). The genital chamber was encircled by two sclerotized rings which are fused posteriorly in younger individuals (Figure 2G), and which sometimes separate again in older specimens (Figure 2H). The medial sclerite was straight, and expanded out from the posterior of the rings anteriorly, separated into two ridges that form a ' $\mathrm{Y}$ ' shaped junction before merging with the anterior lobe. Anteriad to the lobe were two transverse sclerites parallel to the lobe. On both sides, above the sclerotized rings, were two lateral oviducts that connect to the parallel ribs below them. The duct of the spermatechal gland was readily observed in younger samples (Figure $2 \mathrm{G})$, and less visible in the full-grown adults.

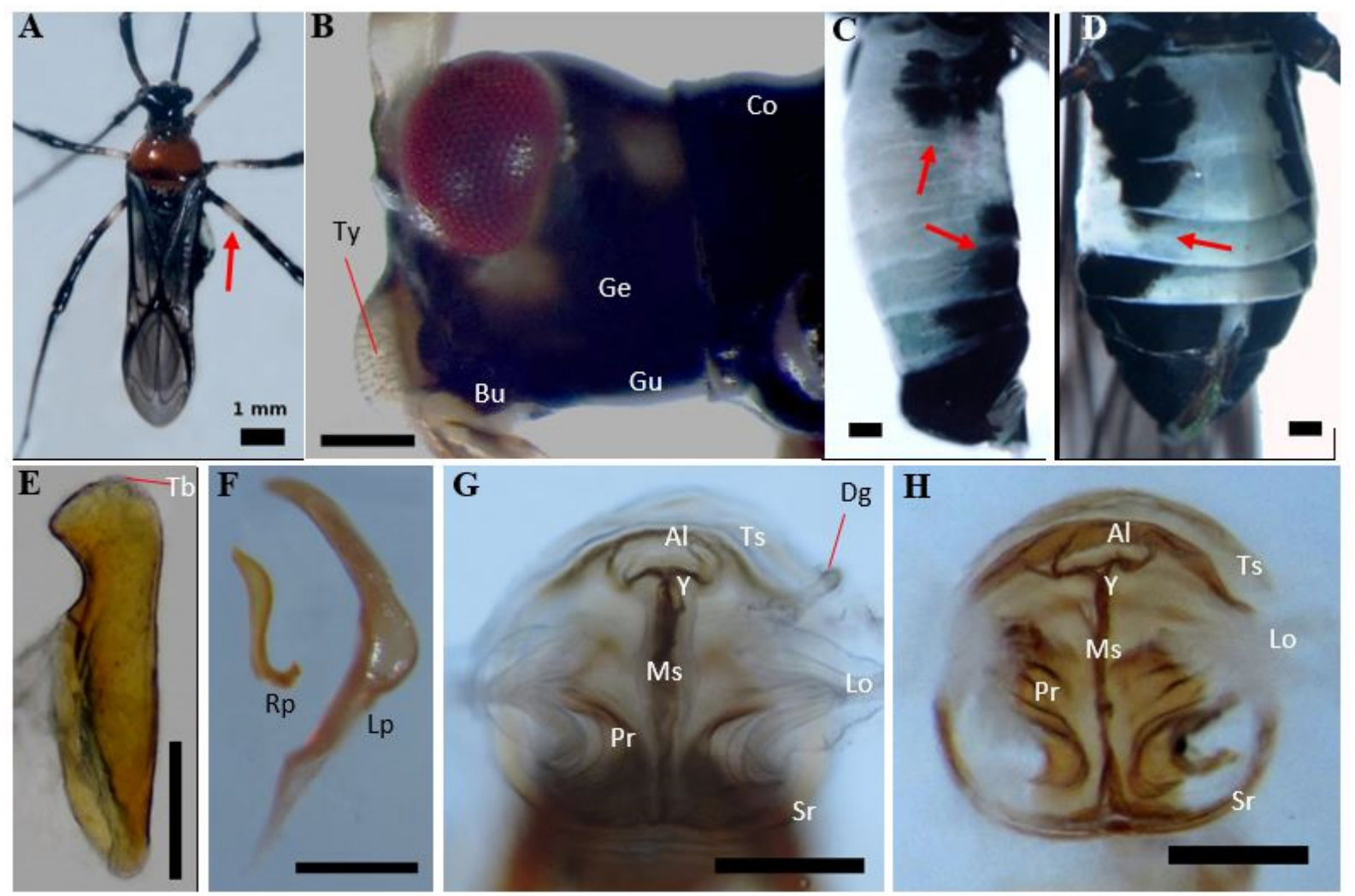

Figure 2. The external morphology and genitalia of the adults of Yogyakarta Helopeltis. A: habitus; B: lateral view of the head; C, D: abdomen of male and female; E: male lobal sclerite; F: male parameres; G, H: female genital chamber. Al: anterior lobe; Bu: buccula; Co: collar; Dg: duct of spermathecal gland; Ge: gena; Gu: gula; Lo: lateral oviduct; Lp: left paramere; Ms: medial sclerite; Pr: parallel ribs; Rp: right paramere; Sr: sclerotized rings; Tb: tubercles; Ts: transverse sclerite; Ty: Tylus; Y: 'Y' junction. Arrows: A: pale band; B, C: dark bands on abdominal segments. Unspecified bars $=200 \mu \mathrm{m}$.

Table 1. The survivorship of Yogyakarta Helopeltis reared on cucumber fruit (each replication $=15$ )

\begin{tabular}{lccc}
\hline Replication & Male & Female & Total \\
\hline 1 & 0.73 & 0.27 & 0.94 \\
2 & 0.57 & 0.43 & 0.83 \\
3 & 0.69 & 0.31 & 0.82 \\
\hline Average & 0.66 & 0.34 & 0.86
\end{tabular}




\section{The eggs}

Females in our sample lay between 45-366 eggs within a life span of 9-44 days (Table 4). Eggs are laid singly or in cluster (Table 3 ). A cluster may consist of 2-8 eggs, with 2 most commonly observed. All eggs are ovo-elongated, white, shiny, slightly bent dorsally, and pointed apically (Figure 3A). The tips are round, with the center slightly wider than either end. The eggs are generally inserted in fruit, around the pit left by the fruit stalk and into the bended part of the exocarp. They are laid subsurface, invisible from the outside, except for a pair of filaments protruding from the fruit (Figure 3B). The filaments--or the "respiratory horns"-- were of unequal length; the longer horn was $0.57(0.54-0.65) \mathrm{mm}$ while the shorter one was $0.30(0.29-0.32) \mathrm{mm}$. An operculum was located between the horns. The average length of the eggs was $1.31 \mathrm{~mm}$ (Table 4), and the width averages $0.21 \mathrm{~mm}$. Most eggs hatched after 8-9 days. Prior to hatching, the tip of the eggs, or the operculum, emerges from the surface showing its black head (Figure 3C).

\section{The nymphs}

Nymphs pass through five instar stages. In our collected sample, they spent a total of 12-19 days to complete the five instars and gradually

Table 2. Mean and range (mm, standard error) body measurements of adult Yogyakarta Helopeltis $(\mathrm{n}=10)$

\begin{tabular}{lcccc}
\hline \multirow{2}{*}{ Length/width } & \multicolumn{2}{c}{ Mean (range) } \\
\cline { 2 - 5 } & Male & SE & Female & SE \\
\hline Antennal segment 1 & $2.51(2.44-2.66)$ & 0.02 & $2.73(2.66-2.78)$ & 0.01 \\
Antennal segment 2 & $4.37(3.44-4.77)$ & 0.14 & $4.38(3.77-4.72)$ & 0.08 \\
Posterior of pronotum & $1.43(1.40-1.51)$ & 0.01 & $1.70(1.67-1.71)$ & 0.00 \\
Front femur & $1.94(1.67-2.13)$ & 0.04 & $2.06(1.91-2.18)$ & 0.03 \\
Front tibia & $2.65(2.50-2.80)$ & 0.03 & $2.81(2.61-2.94)$ & 0.03 \\
Hind femur & $2.53(2.53-2.75)$ & 0.02 & $2.62(2.60-2.77)$ & 0.02 \\
Hind tibia & $3.32(3.27-3.62)$ & 0.03 & $3.57(3.50-3.72)$ & 0.02 \\
\hline
\end{tabular}

Table 3. Average number of eggs deposited by the female Yogyakarta Helopeltis. *Number of deposited eggs daily is observed during the first six days of egg laying period

\begin{tabular}{lcc}
\hline Parameter & No. of eggs & Percentage \\
\hline Total & Mean (range) & - \\
Daily deposit* & $143.20(45-366)$ & - \\
$\quad$ Singly & $14(8-21)$ & $51.0 \%$ \\
In cluster of 2 & $7.2(3-13)$ & $24.1 \%$ \\
In cluster of 3 & $3.4(0-5)$ & $19.1 \%$ \\
In cluster of 4 & $2.7(0-3)$ & $5.7 \%$ \\
\hline
\end{tabular}

Table 4. Average duration (day) and body length (mm, standard error) of different developmental life stages of Yogyakarta Helopeltis $(\mathrm{n}=10)$

\begin{tabular}{lccc}
\hline Stage of development & Period (range) & Length (range) & SE \\
\hline Egg & $8.50(7-11)$ & $1.31(1.27-1.33)$ & 0.01 \\
Nymph 1 & $3.30(3-4)$ & $1.65(1.55-1.78)$ & 0.02 \\
Nymph 2 & $2.20(2-3)$ & $2.38(2.22-2.78)$ & 0.05 \\
Nymph 3 & $2.30(2-3)$ & $3.24(3.00-3.44)$ & 0.04 \\
Nymph 4 & $2.90(2-4)$ & $4.58(4.44-4.77)$ & 0.03 \\
Nymph 5 & $4.30(3-5)$ & $5.53(5.22-5.77)$ & 0.04 \\
Male & $33.20(16-54)$ & $6.50(6.11-6.88)$ & 0.07 \\
Female & $16.90(9-44)$ & $7.75(7.22-8.33)$ & 0.09 \\
\hline
\end{tabular}


gain length with each consecutive instar (Table 4). All nymph instars were pear-shaped with yelloworange to brown coloration (Figure 3D-H). First instar (Figure 3D). All first instars were covered with pronounced setae. The head and the abdomen were yellow-orange in colour; the thorax and the legs were yellow. The first antennal segment was yellow but the other segments were dark yellow. The eyes were red with a red band extending latero-posteriorly. The scutellar spine was absent. Bands on the lateral side of the body and along the middle of the dorsal part of the abdomen were reddish orange. The abdominal band has a reddishorange spot on one third of its circumference, which encircles the opening of the scent gland, a structure that was present in all instars. The last abdominal segment was reddish posteriorly and darker laterally. Second instar (Figure 3E). Second instars in our collected sample were less hairy than the first instars, and the setae were mostly found on the antennae. They were orange grey in coloration, especially the lateral body, head, thorax, basal abdominal segment, and the dorsal band on the abdomen. The first antennal segment was orange; the remaining segments were brown. The eyes were dark red, and the latero-posterior band remains obvious. The scutellar spine was now present; it was short, slightly bent basally and orange in coloration. Third instar (Figure 3F). The third instars were distinct from the second by the presence of wing buds which are short and dark orange. The lateral part of the body was deep orange. The legs and the first antennal segments were orange with dark grey bands; the other segments were dark brown. The eyes were dark red with distinct red bands. The scutellar spine was now longer, with an orange knob and darker lower section. The middle dorsal band and the orange spot were pronounced. Fourth instar (Figure 3G). The fourth instars' head, thorax and posterior section of the abdomen were orange. The eyes were deep red, with a latero-posterior red band. The legs and first antennal segments were orange with dark grey bands; the other segments were dark brown. The knob of the scutellar spine was orange, and the lower part dark brown. The dark brown wing buds had grown posteriorly to cover one third of the abdomen. Fifth instar (Figure 3H). The fifth instars had a rusty-orange head. The first antennal segment was orange; the others were rusty-orange. The legs were pale orange with dark grey bands; the thorax and the abdomen were orange brown. The scutellar spine had a dark grey lower section and orange knob. The dark brown wing buds were extended posteriorly covering two thirds of the abdomen.

\section{DISCUSSION}

Our results indicate that all the samples collected from three different locations in Yogyakarta are of one species, and that this species is $H$. bradyi, not $H$. antonii. The details
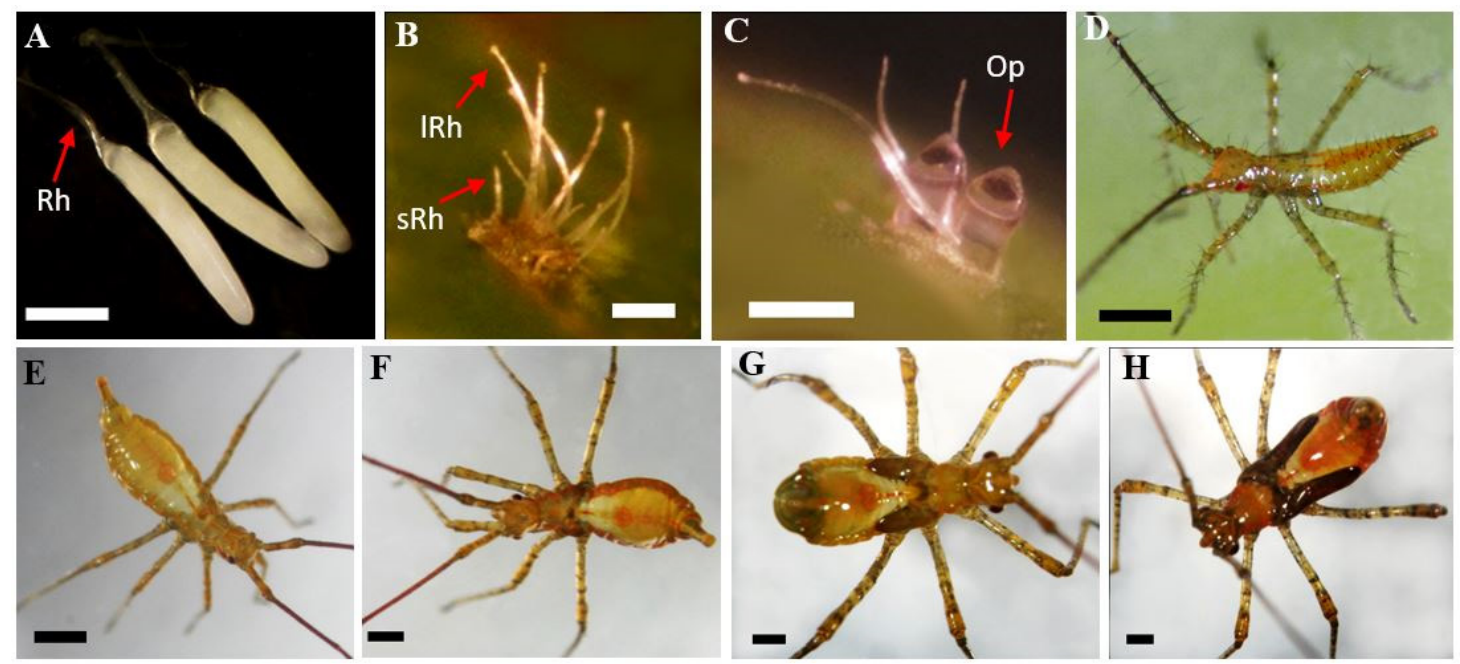

Figure 3. The immature stages of Yogyakarta Helopeltis. A: eggs extracted from gravid female; B: eggs inserted beneath cucumber exocarp, showing longer $(\mathrm{lRh})$ and shorter respiratory horns (sRh); C: surfaced eggs operculum before hatching; and $\mathrm{E}-\mathrm{H}$ : the 1st to 5th instar nymphs. Op: operculum; $\mathrm{Rh}$ : respiratory horns. Bar $=500 \mu \mathrm{m}$. 
of morphological observations especially the genitalia as key characters for identification are given (Table 5) and discussed below.

Externally, the adults of Helopeltis individuals sampled from Yogyakarta are more similar to $H$. bradyi than to $H$. antonii. When we compared their femora, abdominal sterna, and head patterns, the most readily observed and differentiating external character was the leg. The legs of all male and female samples have a pale band at the base of each of their femurs. These bands are only present on the fore and mid femora of $H$. antonii, but present on all femora of $H$. bradyi (Stonedahl 1991) therefore presence of the bands in our sample individuals supports their identification as $H$. bradyi. Using abdominal coloration as an identifiying charcter, our results were indeterminate. In lateral view, all the abdominal segments of female adult Helopeltis individuals sampled from Yogyakarta have dark patches. In the males, all segments are dark except for segments IV and V which are pale. Prior research notes that for both female $H$. antonii and H. bradyi (Stonedahl 1991), dark patches are only found on the first three abdominal segments and are absent on the middle segments (IV, V, VI) (Figure 4B). In this study, only the newly moulted females have dark patches, restricted to the first three segments, whereas as they matured, all sternal segments of the abdomen eventually were coloured by the dark patches. Unfortunately, in Stonedahl (1991) there is no detailed information on the age of the observed specimens to further clarify or confirm whether the abdominal sternal pattern of the full-grown females matches either of $H$. antonii or $H$. bradyi. The colour pattern on the head of the sampled Helopeltis individuals from Yogyakarta were also not determinative for identfication. The pattern we observed in the Yogyakarta individualsis similar to both that of $H$. antonii and of H. bradyi (Stonedahl 1991), that is one pale spot under the eyes, and two others near the collar (Figure 4A). However, although the spot under the eyes and near the collar were present in our Yogyakarta samples, the pale spot beside the gena, near the collar was rarely found on the heads of the fully matured adults in our sample, especially the male of the studied Helopeltis. In his report Stonedahl (1991) uses similar figure

Table 5. Comparison of adult characters of Helopeltis antonii and H. bradyi (Stonedahl 1991) vs. Yogyakarta Helopeltis

\begin{tabular}{|c|c|c|c|}
\hline Character & H. antonii & H. bradyi & Yogyakarta Helopeltis \\
\hline Body length & $5.9-8.0 \mathrm{~mm}$ & $6.6-8.6 \mathrm{~mm}$ & $6.1-8.3 \mathrm{~mm}$ \\
\hline Antennal length & $\begin{array}{l}\text { Segment I slightly longer than } \\
\text { posterior width of pronotum } \\
\text { (ratio: males, } 1.20: 1-1.45: 1 \text {; } \\
\text { females, } 1.05: 1-1.30: 1 \text { ) }\end{array}$ & $\begin{array}{l}\text { Segment I much longer than } \\
\text { posterior width of pronotum } \\
\text { (ratio: males, } 1.50: 1-1.85: 1 \text {; } \\
\text { females, } 1.45: 1-1.60: 1 \text { ) }\end{array}$ & $\begin{array}{l}\text { Similar to } H . \text { bradyi, but } \\
\text { larger ratio (ratio: males, } \\
1.74: 1-1.77: 1, \text { females, } \\
1.59: 1-1.62: 1 \text { ) }\end{array}$ \\
\hline $\begin{array}{l}\text { Position of the pale } \\
\text { spot on the head }\end{array}$ & $\begin{array}{l}\text { Apex of tylus, under and behind } \\
\text { the eyes near the pronotal collar } \\
\text { and posterior to gena }\end{array}$ & Similar to $H$. antonii & Similar to $H$. antonii \\
\hline $\begin{array}{l}\text { Pale band on } \\
\text { femora }\end{array}$ & Fore and middle femora only & $\begin{array}{l}\text { Fore, middle, and hind } \\
\text { femora }\end{array}$ & Similar to $H$. bradyi \\
\hline $\begin{array}{l}\text { Dark patch on } \\
\text { abdominal sterna }\end{array}$ & Only on segment I-III & Similar to $H$. antonii & $\begin{array}{l}\text { On each segments on } \\
\text { full-grown female; } \\
\text { on segments I-III on } \\
\text { newly-moulted female. } \\
\text { Indeterminate for } \\
\text { identification. }\end{array}$ \\
\hline Male lobal sclerite & $\begin{array}{l}\text { 'D' shaped; pointed posteriorly, } \\
\text { gradually widened anteriorly; } \\
\text { tubercles cover half of dorsum }\end{array}$ & $\begin{array}{l}\text { Two distinct shapes; knife- } \\
\text { like and blade-like, tubercles } \\
\text { confined on apex }\end{array}$ & $\begin{array}{l}\text { Knife-like, tubercles } \\
\text { confined on apex. Same } \\
\text { as } H . \text { bradyii }\end{array}$ \\
\hline $\begin{array}{l}\text { Female genital } \\
\text { chamber }\end{array}$ & $\begin{array}{l}\text { Sclerotized rings separated } \\
\text { posteriorly, medial sclerite small, } \\
\text { not reaching posterior part of } \\
\text { the rings; anterior lobe poorly } \\
\text { developed }\end{array}$ & $\begin{array}{l}\text { Sclerotized rings fused } \\
\text { posteriorly; medial sclerite } \\
\text { strong and long, sometimes } \\
\text { forms 'Y' junction with the } \\
\text { well-developed anterior lobe }\end{array}$ & $\begin{array}{l}\text { Similar to } H \text {. bradyi, but } \\
\text { the medial sclerite always } \\
\text { forms a 'Y' junction } \\
\text { with the well-developed } \\
\text { anterior lobe }\end{array}$ \\
\hline
\end{tabular}


(Figure 4A) all three facial spots to describe both $H$. antonii and $H$. bradyi, which were not always observed in the $H$. bradyi studied in this report.

The characteristics of the lobal sclerite observed in male Helopeltis individuals sampled from Yogyakarta, matches the identifying characteres of H. bradyi (Figure 4C.) described by Stonedahl (1991). The lobal sclerite of Yogyakarta samples were knife-like, with a "blade" pointing posteriorly, straight medially, and a sharply bent ventro-anteriorly to create a part resembling a knife handle, with few tubercles $(\mathrm{Tb})$ on the apex. Some Javanese $H$. bradyi have been observed with an alternative shape of lobal sclerite (Figure 4D), different in that the anterior part is not bent. This alternative morphology was not observed in the currently studied samples from Yogyakarta. The male lobal sclerite of the studied samples thus matches one variant of $H$. bradyii morphology, which furthermore is quite distinct from that of $H$. antonii (Figure 4E). The lobal sclerite in $H$. antonii has a pointed posterior end, which gradually widens anteriorly to appear like a ' $D$ ' letter. Also, in $H$. antonii the tubercles on the lobe are abundant, scattering from the apex down to cover almost half of the dorsum. This differs from the morphology of the samples from Yogyakarta. Thus the morphology of the lobal sclerite seems to confirm identifcation of sampled individuals as $H$. bradyii. The only observation to contradict this finding is that of the right paramere. Among the sample Helopeltis individuals, the right paramere is similar to that of $H$. antonii (Figure $4 \mathrm{~F})$. However, the left paramere does not match that found in $H$. antonii; instead the left paramere for the Yogyakarta individuals' is wider mediodorsally and somewhat straighter posteriorly. Overall the morphology of the lobal sclerite supports idenfication of the Yogyakarta Helopeltis samples as belonging to $H$. bradyii.

The observed morphology of the female genital chamber of our collected sample Helopeltis resembles that of the H. bradyi individuals (Figure 4G) described by Stonedahl (1991) from the Javanese specimens. The chamber is characterized by posteriorly fused sclerotized rings on younger individuals, that sometimes split in mature individuals by the sclerotization process. There is a ' $\mathrm{Y}$ ' shaped junction between the medial sclerite and the anterior lobe, and there are two transverse sclerites (instead of one) that run parallel to the anterior lobe. The two chambers of Yogyakarta Helopeltis sampled in this study were from individuals of different ages, with younger insects showing less sclerotized chambers than the heavily sclerotized ones of fully matured females. The genital chamber morphology observied in our samples is different from that reported for other studies of Javanese $H$. bradyi (Figure 4H). Our samples exhibit a bent medial sclerite and an absence of the ' $\mathrm{Y}$ ' shaped junction. Furthermore, the our collected Helopeltis' genital chamber is exceptionally distinct from that of $H$. antonii (Figure 4I) by the following characters; the small
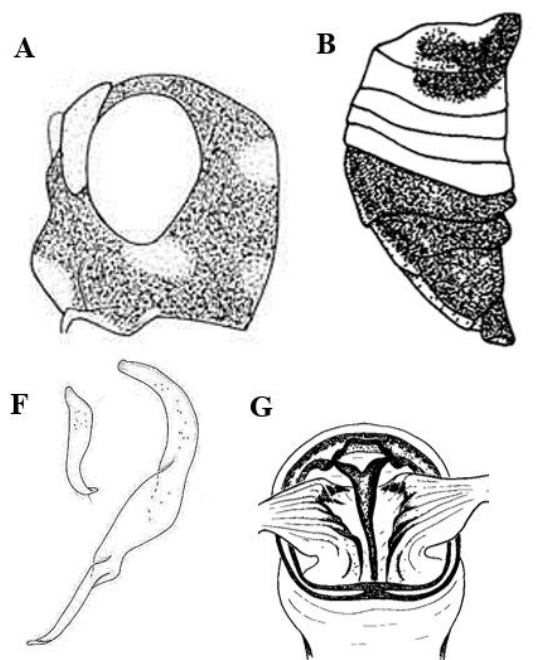

G

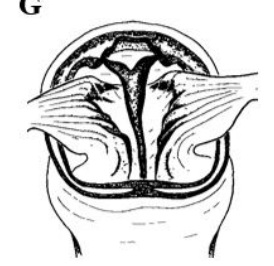

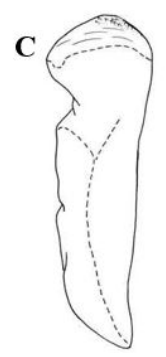
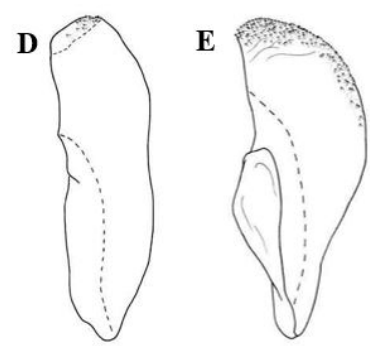

H

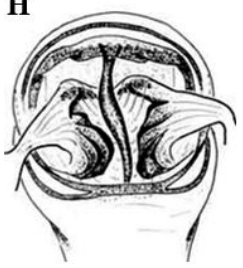

I

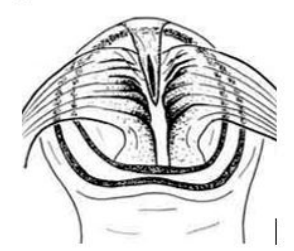

Figure 4. Sketches of Helopeltis antonii and H. bradyi (Stonedahl 1991). The lateral view of the head (A) and the abdomen of $H$. antonii and $H$. bradyi (B); the male lobal sclerite of $H$. bradyi of Java (C, $\mathrm{D})$, and $H$. antonii $(\mathrm{E})$; the right (smaller) and left (bigger) paramere of $H$. antonii $(\mathrm{F})$; and the female genital chamber of $H$. bradyi of Java $(\mathrm{G}, \mathrm{H})$ and $H$. antonii (I). 
and short medial sclerite confined within a poorly developed anterior lobe; parallel ribs which are finely arranged; and posteriorly separated sclerotized rings.

Female adults in our Yogyakarta sample population laid eggs mostly singly, and the eggs were slightly larger than generally observed among Helopeltis. On cucumber fruit and under laboratory conditions of $23{ }^{\circ} \mathrm{C}$ and $70 \%$ humidity, $51 \%$ of the eggs of the collected Helopeltis were laid singly, while $24.1 \%$ and $19.1 \%$ of them were laid in clusters of two and three respectively. Similarly, Devasahayam (1988) found that $43.6 \%$ of $H$. antonii eggs are inserted singly, while Stonedahl et al. (1995) observed that female H. pernicialis mostly laid their eggs singly when reared on cashew leaves in an air conditioned environment at $21-31{ }^{\circ} \mathrm{C}$ and relative humidity of $45-70 \%$. Devasahayam \& Nair (1986) observed 2-6 eggs within a cluster laid by $H$. antonii on cashew plants, while in the current study we found $2-8$ eggs observed within a cluster on cucumber fruit. The length of the eggs in our sample population not including the respiratory horn average $1.31 \mathrm{~mm}$ or about $6 \times$ their width (Table 3 ). These eggs are larger than those of $H$. theivora, H. clavifer, $H$. schoutedeni, and $H$. antonii, which range in length from 1.0-1.23 mm (Miller 1941; Smith 1979; Ambika \& Abraham 1979; Dwomoh et al. 2008 consecutively). The mean length of the respiratory horns of these eggs $(0.57 \mathrm{~mm}$ and $0.30 \mathrm{~mm})$ is slightly longer than the longer horn $(0.5 \mathrm{~mm})$ but also shorter than the shorter horn $(0.4 \mathrm{~mm})$ of $H$. schoutedeni (Dwomoh et al. 2008) and H. antonii (Ambika \& Abraham 1979).

The nymphs and adults in our sample population fromYogyakarta (Table 4) were larger than those of $H$. theivora (Miller 1941) and $H$. clavifer (Smith 1979) but similar in size to those of H. antonii (Ambika \& Abraham 1979). They were all yellowish orange to brown in coloration. The first instar is without the scutellar spine and lacks setae. The spine appears during the second instar. The wing buds start to grow on the third instar which become longer as they reach the final instar. Similar observations of morphological development have been reported for $H$. clavifer (Smith 1979) and H. antonii (Ambika \& Abraham 1979). In general, the males in our sample 18 population were smaller than females. The body length of males and females ranged between $6.11-6.88 \mathrm{~mm}$ and $7.22-8.33 \mathrm{~mm}$ consecutively. Both measurements fall within the observed range for $H$. bradyi (6.6-8.6 mm Stonedahl 1991), and are slightly bigger than that of $H$. antonii (5.9 or $6.0 \mathrm{~mm}$ and $8.0 \mathrm{~mm}$, Stonedahl 1991; Ambika \& Abraham 1979), and significantly larger than that of $H$. theivora (4.8 $\mathrm{mm}$ and $5.7 \mathrm{~mm}$, Miller 1941).

For individuals in our Yogyakarta population, the 1st antennal segment is shorter than the 2nd on both males and females, at a proportion of $0.57 \times$ and $0.62 \times$ respectively (Table 2 ). This proportion was also found by Miller (1941) on $H$. theobramae (now identified as $H$. theivora), and Ambika \& Abraham (1979) on H. antonii (ca. $0.42 \mathrm{~mm}$ and $0.73 \mathrm{~mm}$ ). The ratio between the 1 st and the remaining segments is slightly bigger in males than in females in our collected sample. The 1st antennal segment is also longer than the width of the pronotum; the mean ratios of 1.74 : $1-1.77: 1$ in the males and $1.59: 1-1.62: 1 \mathrm{~mm}$ in females are within the ranges previously found for $H$. bradyi $(1.50-1.85 \mathrm{~mm}$ and $1.45-1.60 \mathrm{~mm}$ respectively, Stonedahl 1991). Lesser variation among the Yogyakarta Helopeltis is predicted by the smaller sample size coming from a limited geographic area, as compared to the Stonedahl (1991) review which included samples from Sri Lanka, south and north-east India, Malaysia, Java, and Sumatera.

The recorded longevity of our Helopeltis samples varied. The average longevity of the female adults reared on cucumber fruit was 16.9 d, roughly similar to that found by Wardojo (1983) and Kilin \& Atmaja (2000) of 17.6 and 18.9 days for $H$. antonii; however, the species used in these two studies were not properly confirmed as $H$. antonii and therefore their results should be attributed to $H$. bradyi rather than to $H$. antonii. In the current study, males lived for an average of $33 \mathrm{~d}$, substantially longer than the 19.8 and $22.1 \mathrm{~d}$ averages reported by Kilin \& Atmaja (2000) and Wardojo (1983). Ambika \& Abraham (1979) conducted a biological study of $H$. antonii raised on cashew seedlings, and found that males and females is only lived for 5.2 and $6.5 \mathrm{~d}$ consecutively at $28{ }^{\circ} \mathrm{C}$. The survivorship of our cucumber-reared Helopeltis reached 86\% 
(Table 1), with the highest mortality occuring among the first instar population, due to unhatched eggs or the inability of neonate nymphs to detach themselves from the eggs. Cucumber fruit is not the natural host of this insect, therefore the use of cucumber as food might affect the entire first instar developmental stage, including fecundity and hatchability. Sundararaju \& Sundarababu (1998) observed the influence of different host plants viz. neem, guava, and cashew and different parts of these plants, on the fecundity of $H$. antonii. In addition, Devasahayam \& Nair (1986) suggested that the influence of temperature and humidity which were varied among experimental groups of Helopeltis species caused variation in longevity, female fecundity, and oviposition period.

\section{CONCLUSION}

We conclude that the external and genital morphological characters of Yogyakarta Helopeltis examined in this study closely resembled those of $H$. bradyi. The presence of a white band on hind femora, the longer first antennae when compared to the posterior width of pronotum, and the morphology of male and female genitalia confirm that the species is $H$. bradyi. While morphology confirms the identification of our Yogyakarta sample to be $H$. bradyi, the biology of our samples is similar to that usually reported for $H$. antonii locally. This indicates that previously reported observations of $H$. antonii from other regions in Java might actually be the result of misidentification of populations that actually belong to species $H$. bradyi. Further study is needed to bolster species identification and more clearly differentiate between $H$. bradyii and $H$. antonii, both by examining fully grown adults, and also by studying morphological and biological changes in laboratory-reared insects.

\section{ACKNOWLEDGMENT}

We thank the following personnel from the Department of Plant Protection, Faculty of Agriculture, Universitas Gadjah Mada, for sample provision and laboratory assistance: Don Kadja,
Burhan Murprasetyo, Zenrita Elnursanti, Dessi Rahma Sulistyani, and Yustina Yuni Krisnawati. We are in debted to Dr. Chris Beadle (CSIRO) for commenting on the draft. This paper is part of the first author's doctorate project funded by a scholarship from the Ministry of Agriculture.

\section{REFERENCE}

Ambika B, Abraham CC. 1979. Bio-ecology of Helopeltis antonii Sign. (Miridae: Hemiptera) infesting cashew trees. Entomon 4:335-342.

Atkinson ET. 1897. Rhynchota. Notes on Indian Economic Entomology I:175-190.

Atmaja WR. 2012. Pengendalian Helopeltis secara Terpadu pada Tanaman Perkebunan. Bogor: Unit Penerbitan dan Publikasi Balai Penelitian Tanaman Rempah dan Obat.

BBP2TP Surabaya. 2011. Laporan Tahunan OPT Perkebunan di Wilayah Kerja BBP2TP Surabaya. Jombang: BBP2TP Surabaya.

Bergroth E. 1889. Notes on two Capsidae attacking the cinchona plantations in Sikkim. Entomologist's Monthly Magazine 25:271-272.

Devasahayam S. 1988. Mating and oviposition behavior of tea mosquito bug Helopeltis antonii Signoret (Heteroptera: Miridae). Journal Bombay Natural History Society 85: 212-214.

Devasahayam S, Nair CPR. 1986. The tea mosquito bug Helopeltis antonii Signoret on cashew in India. Journal Plantation Crops 14:1-10.

de Moraes GJ. 1987. Importance of taxonomy in biological control. International Journal of Tropical Insect Science 8:841-844. doi: http:// dx.doi.org/10.1017/S1742758400023031.

De Silva MD. 1957. A new species of Helopeltis (Hemiptera-Heteroptera, Miridae) found in Ceylon. Bulletin Entomological Research 48: 459-461. doi: http://dx.doi.org/10.1017/S000 7485300002637.

Djamin A. 1980. Strategi pengendalian hama coklat. Kumpulan Makalah Konferensi Coklat Nasional (Medan, 16-18 September 1980). pp. 44-45. Medan.

Dwomoh EA, Afun JVK, Ackonor JB. 2008. Laboratory studies of the biology of Helopeltis schoutedeni Reuter (Hemiptera: Miridae), a major sucking pest of cashew (Anacardium occidentale Linn.). Journal of Cell and Animal Biology 2:055-062. 
Karmawati E. 2010. Pengendalian hama Helopeltis spp. pada jambu mete berdasarkan ekologi: strategi dan implementasi. Majalah Pengembangan Inovasi Pertanian 3:102-119.

Kilin D, Atmadja WR. 2000. Perbanyakan serangga Helopeltis antonii Sign. pada buah ketimun dan pucuk jambu mente. Jurnal Penelitian Tanaman Industri 5:119-122.

Miller DR, Rossmann AY. 1995. Systematics, biodiversity, and agriculture. BioScience 45: 680-686. doi: http://dx.doi.org/10.2307/1312673.

Miller NCE. 1941. Insects associated with Cocoa (Theobroma cacao) in Malaya. Bulletin of Entomological Research 32:1-15. doi: http:// dx.doi.org/10.1017/S0007485300005186.

Pusat Penelitian Kopi dan Kakao [Puslitkoka]. 2004. Panduan Lengkap Budi daya Kakao. Jakarta: Agromedia Pustaka.

Signoret V. 1858. Descriptions de nouvelles especes d'Hemipteres. II. Note sur les. Hemipteres Heteropteres de la famille des unicellules. Annales de la Societe Entomologique de France 3:499-50.

Siswanto, Muhammad R, Omar D, Karmawati E. 2008. Dispersion pattern of Helopeltis antonii Signoret (Hemiptera:Miridae) on Cashew Plantation. Jurnal Penelitian Tanaman Industri 14:149-154.

Smith ECS. 1979. Descriptions of the immature and adult stages of the cocoa mirid Helopeltis clavifer (Heteroptera: Miridae). Pacific Insects 20:354-361.

Stonedahl GM. 1991. The oriental species of Helopeltis (Heteroptera: Miridae): a review of economic literature and guide to identification. Bulletin Entomological Research 81:
465-490. doi: http://dx.doi.org/10.1017/S000748 5300032041.

Stonedahl GM, Malipatil MB, Houston W. 1995. A new mirid (Heteroptera) pest of cashew in northern Australia. Bulletin Entomological Research 85:275-278. doi: http://dx.doi.org/ $10.1017 / \mathrm{S} 0007485300034362$.

Sudarmadji D. 1979. Pembiakan Helopeltis antonii di Laboratorium. Di dalam: Kongres Nasional Biologi IV (Bandung, 10-12 Juli 1979). Bandung: Perhimpunan Biologi Indonesia.

Sundararaju D, Sundarababu PC. 1998. Life tables studies of Helopeltis antonii Sign. (Heteroptera: Miridae) on neem, guava, and cashew. Journal Entomological Research 22:241-244.

Walker F. 1873. Catalogue of The Specimens of Hemiptera Heteroptera in The Collection of The British Museum. London: Printed for the Trustees of the British Museum.

Wardojo S. 1983. Pembiakan Helopeltis antonii Sign. di laboratorium pada buah kopi. Menara Perkebunan 51:33-38.

Waterhouse CO. 1886. Some observations on the teabugs (Helopeltis) of India and Java. Transactions of the Royal Entomological Society of London 34:457-460.

Waterhouse CO. 1888. VIII. Additional observations on the tea-bugs (Helopeltis) of Java. Transactions of the Royal Entomological Society of London 36:207. doi:10.1111/j.1365-2311.1888. tb01309.x.

Wiryadiputra S. 1997. Pengelolaan hama Helopeltis pada tanaman kakao. Warta Pusat Penelitian Kopi dan Kakao 13:1-12. 